\title{
Informasi Kesehatan melalui Penyuluhan, Poster dan Leaflet di Dusun Talang Parit Desa Kemingking Dalam Kecamatan Taman Rajo Provinsi Jambi
}

\author{
Yulianis $^{1}$, Ayu Ulil Fauziah ${ }^{2}$, Diah Kusumawati ${ }^{3}$ \\ 1,2,3 Prodi Farmasi, STIKES Harapan Ibu Jambi,Jambi, Indonesia \\ Email: yulianisaljazira@yahoo.com
}

Submitted : 14/05/2020

Accepted: 21/05/2020

Published:16/06/2020

\begin{abstract}
Talang Parit Hamlet Kemingking Dalam Village is one of the Villages located in Taman Rajo SubDistrict, Muaro Jambi District, where most of its residents work as factory laborers and gardeners. Gastritis, Gout and Hypertension are the 3 biggest diseases in RT.09 Talang Parit Hamlet, Kemingking Dalam Village. Therefore, health counseling was conducted to the community RT.09 Talang Parit Hamlet related to gastritis, gout, and hypertension. Health education is one way that can be used to convey health information. Health counseling can be done in two ways, which can be directly (face to face) and indirectly (mass media). This activity aims to increase public knowledge about diseases including symptoms, prevention and treatment, to increase public knowledge about natural resources that can be processed to overcome some diseases and about the classification of drugs, and to overcome errors in the use of drugs. This activity uses the method of providing information through direct media, namely counseling and indirectly using posters and leaflets. Respondents involved were 36 adults and parents. The results of this outreach activity indicate that there is an influence of health education before and after on the level of community knowledge
\end{abstract}

Keywords: gastritis, gout, hypertension, health counseling.

\begin{abstract}
Abstrak
Dusun Talang Parit Desa Kemingking Dalam merupakan salah satu Desa yang terletak di Kecamatan Taman Rajo Kabupaten Muaro Jambi yang sebagian besar warganya bekerja sebagai buruh pabrik dan berkebun. Gastritis, Asam urat dan Hipertensi merupakan 3 penyakit terbesar di RT.09 Dusun Talang Parit Desa Kemingking Dalam. Oleh karena itu dilakukan penyuluhan kesehatan kepada masyarakat RT.09 Dusun Talang Parit terkait penyakit Gastritis, Asam urat, dan Hipertensi. Penyuluhan kesehatan adalah salah satu cara yang dapat digunakan untuk menyampaikan informasi kesehatan. Penyuluhan kesehatan dapat di lakukan melalui dua cara yaitu dapat secara langsung (tatap muka) dan secara tidak langsung (media masa). Kegiatan ini bertujuan untuk meningkatkan pengetahuan masyarakat tentang penyakit meliputi gejala, pencegahan dan pengobatannya, untuk meningkatkan pengetahuan masyarakat tentang sumber bahan alam yang dapat diolah untuk menanggulangi beberapa penyakit dan tentang penggolongan obat, serta untuk menanggulangi terjadinya kesalahan dalam penggunaan obat. Kegiatan ini menggunakan metode pemberian informasi melalui media langsung yaitu penyuluhan dan tidak langsung yaitu menggunakan poster dan leaflet. Responden yang terlibat sebanyak 36 orang usia dewasa dan orang tua. Hasil dari kegiatan penyuluhan ini menunjukKan bahwa adanya pengaruh penyuluhan kesehatan sebelum dan sesudah terhadap tingkat pengetahuan masyarakat.
\end{abstract}

Kata kunci: asam urat, gastritis, hipertensi, penyuluhan kesehatan 


\section{PENDAHULUAN}

Desa Kemingking Dalam Kecamatan Taman Rajo Kabupaten Muaro Jambi merupakan daerah industri yang banyak terdapat pabrik atau perusahaan kecil seperti pabrik batu bara, penyulingan minyak sawit, pengemasan garam dan lain lain. Desa Kemingking Dalam melewati beberapa perusahaan tersebut yang jalurnya kurang memadai untuk di lewati masyarakat, karena cenderung terjadi polusi udara.

Masyarakat di Desa Kemingking Dalam khususnya ekonomi di RT.09, umumnya memiliki taraf kehidupan menengah ke bawah dimana umumnya warga setempat bekerja sebagai buruh pabrik dan berkebun seperti karet, duku, durian dan sayur mayur.

Dari data Puskesmas Kemingking Dalam tahun 2019 penyakit terbesar yang terjadi di desa Kemingking Dalam adalah Tabel 1. Data Puskesmas Kemingking Dalam

\begin{tabular}{clc}
\hline No & Nama Penyakit & $\begin{array}{c}\text { Jumlah } \\
\text { Penderita }\end{array}$ \\
\hline 1 & ISPA & 2521 \\
2 & Nesofaringitisakut & 933 \\
3 & Gastritis & 891 \\
4 & Dermatitis & 671 \\
5 & Caries gigi & 611 \\
6 & Sakitkepala & 448 \\
7 & Hipertensi & 401 \\
8 & Demam & 387 \\
9 & Meningitis & 288 \\
10 & Rheumatid & 243 \\
& Jumlah & 7394 \\
\hline
\end{tabular}

Dari survei hasil wawancara yang dilakukan terhadap warga di RT.09 di dapatkan data :

Tabel 2. Data Survei Awal

\begin{tabular}{clc}
\hline No & Nama Penyakit & JumlahPenyakit \\
\hline 1 & Gastritis & 11 \\
2 & Hipertensi & 8 \\
3 & Asam urat & 7 \\
4 & Demam, rematik, & 3 \\
& pilek & \\
5 & Stroke, nyeri & 2 \\
\hline
\end{tabular}

\begin{tabular}{l}
\hline pinggang, diabetes \\
melitus, pegal linu \\
dan kolesterol \\
Tumor payudara, \\
rabun, susah BAB, \\
batu ginjal, \\
pengapuran sendi, \\
tiroid, infeksi \\
saluran kemih \\
(ISK), nyeri dada, \\
udem paru, vertigo \\
dan dermatitis \\
Dari masalah kesehatan yang terjadi
\end{tabular}

di RT.09 Dusun Talang Parit Desa Kemingking Dalam Kecamatan Taman Rajo Provinsi Jambi di lakukan upaya untuk menanggulangi masalah kesehatan tersebut melalui pemberian informasi kesehatan yang bertujuan untuk meningkatkan pengetahuan masyarakat tentang penyakit dan cara penanggulangan berupa gejala dan penyebab penyakit, pencegahan penyakit, serta cara pengobatan menggunakan herbal dan sintetik.

Penyuluhan kesehatan merupakan kegiatan pendidikan kesehtan, yang dilakukan dengan menyebarkan pesan, menanamkan keyakinan sehingga masyarakat tidak saja sadar, tahu dan mengerti, tetapi juga mau dan dapat melakukan anjuran yang berhubungan dengan kesehatan (Maulana, 2009). Dari data diatas Gastritis, Asam urat dan Hipertensi merupakan penyakit yang banyak terjadi di Desa Kemingking Dalam terutama di Dusun Talang Parit RT.09 sehingga ketiga penyakit menjadi permasalahan untuk dilakukannya penyuluhan.

Informasi kesehatan lain yang diberikan adalah penyuluhan tentang penggolongan obat. Hal ini di latar belakangi karena ditemukannya obat bebas, obat bebas terbatas, dan obat keras di warung kelontong yang belum sesuai dengan peraturan perundang-undangan.

Penggunaan media dalam penyuluhan kesehatan langsung dan melalui media massa harus mempertimbangkan usia dan 
minat peserta. Media yang dapat digunakan dalam penyuluhan kesehatan dapat menggunakan media power point, flip chart, media audiovisual, koran, majalah, televisi, radio, dan media lainnya. (Haryani \& Sahar, 2016)

Hasil penelitian Haryani\& Sahar (2016) menunjukan bahwa ada pengaruh bermakna penyuluhan kesehatan langsung dan melalui media massa dengan perawatan hipertensi pada usia dewasa di sebuah kelurahan di kota Depok dan penyuluhan kesehatan melalui media cetak merupakan faktor yang paling dominan berhubungan dengan perawatan hipertensi pada usia dewasa.

Berdasarkan penelitian Muthia, Fitriangga, \& Yanti (2016) di dapatkan bahwa terdapat perbedaan yang bermakna antara tingkat pengetahuan akhir dengan tingkat pengetahuan awal pada responden yang mendapat penyuluhan kesehatan. Penyuluhan kesehatan merupakan suatu kegiatan yang dapat mempengaruhi perubahan perilaku responden, salah satunya perubahan pengetahuan. Dengan di berikannya penyuluhan maka responden mendapat pembelajaran yang menghasilkan suatu perubahan dari yang semula belum mengetahui menjadi mengetahui dan yang dahulu belum memahami menjadi memahami.

Penyuluhan dengan metode ceramah lebih efektif dibandingkan dengan demonstrasi terhadap peningkatan pengetahuan kesehatan. Hal tersebut dikarenakan metode ceramah di nilai lebih efektif digunakan pada pendengar yang lebih dari sepuluh orang namun sering menimbulkan kebosanan jika materi yang disampaikan kurang menarik dan terlalu panjang. (Muthia, Fitriangga, \& Yanti, 2016)

Berdasarkan latar belakang diatas maka dilakukan penyuluhan kesehatan tentang informasi kesehatan melalui penyuluhan, poster dan leaflet di RT.09 Dusun Talang Parit Desa Kemingking
Dalam Kecamatan Taman Rajo Provinsi Jambi.

\section{TARGET DAN LUARAN}

Adapun target luaran dalam penyukuhan kesehatan ini adalah diharapkan masyarakat RT.09 Dusun Talang Parit Desa Kemingking Dalam yaitu dapat mengetahui daan mampu menjelaskan kembali gejala, penyebab, pencegahan serta pengobatan dari penyakit asam urat, gastritis dan hipertensi.

\section{METODE PELAKSANAAN}

Kegiatan dilaksanakan pada hari Kamis, 13 Februari 2020. Kegiatan ini menggunakan metode pemberian informasi melalui media langsung yaitu penyuluhan dan tidak langsung yaitu menggunakan poster dan leaflet. Sasaran pada kegiatan ini yaitu masyarakat RT.09 usia dewasa dan orang tua. Kegiatan ini bertujuan untuk meningkatkan pengetahuan masyarakat tentang penyakit meliputi gejala, penyebab, pencegahan dan pengobatannya, untuk meningkatkan pengetahuan masyarakat tentang sumber bahan alam yang dapat diolah untuk menanggulangi beberapa penyakit dan tentang penggolongan obat, serta untuk menanggulangi terjadinya kesalahan dalam penggunaan obat.

\section{HASIL DAN PEMBAHASAN}

Kegiatan penyuluhan kesehatan ini dilakukan di RT.09 Dusun Talang Parit Desa Kemingking Dalam Kecamatan Taman Rajo Kabupaten Muaro Jambi Provinsi Jambi. Peserta kegiatan adalah masyarakat RT.09 dengan jumlah peserta sejumlah 32 orang usia dewasa dan orang tua dari jumlah masyarakat 169 orang.

Pelaksanaan kegiatan berupa penyuluhan kesehatan terkait penyakit Gastritis, Asam urat serta Hipertensi dan penggolongan obat secara langsung kepada masyarakat dan secara tidak langsung menggunakan leaflet dan poster yang dibagikan. Penyuluhan kesehatan yang di berikan yaitu terkait penyakit Gastritis, 
Asam urat, dan Hipertensi meliputi gejala dan penyebab penyakit, pencegahan penyakit, serta cara pengobatan menggunakan herbal dan sintetik. Adapun bentuk posternya dapat dilihat pada gambar 1, 2 dan 3.

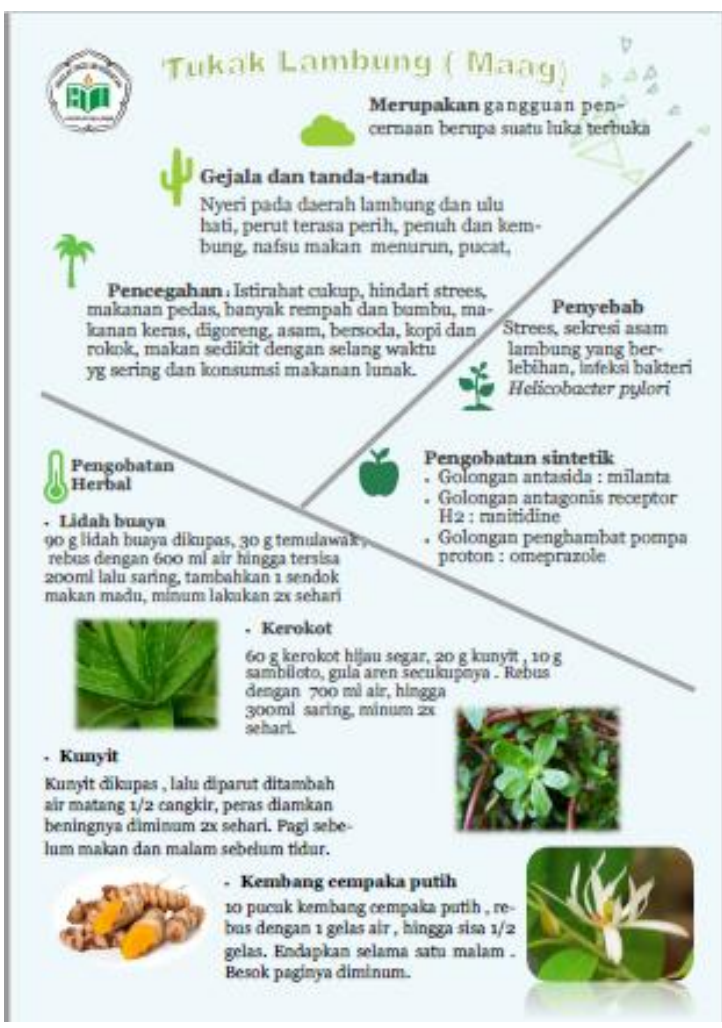

Gambar 1. Poster Penyakit Gastritis(Tussakinah, Masrul, \& Burhan, 2018).

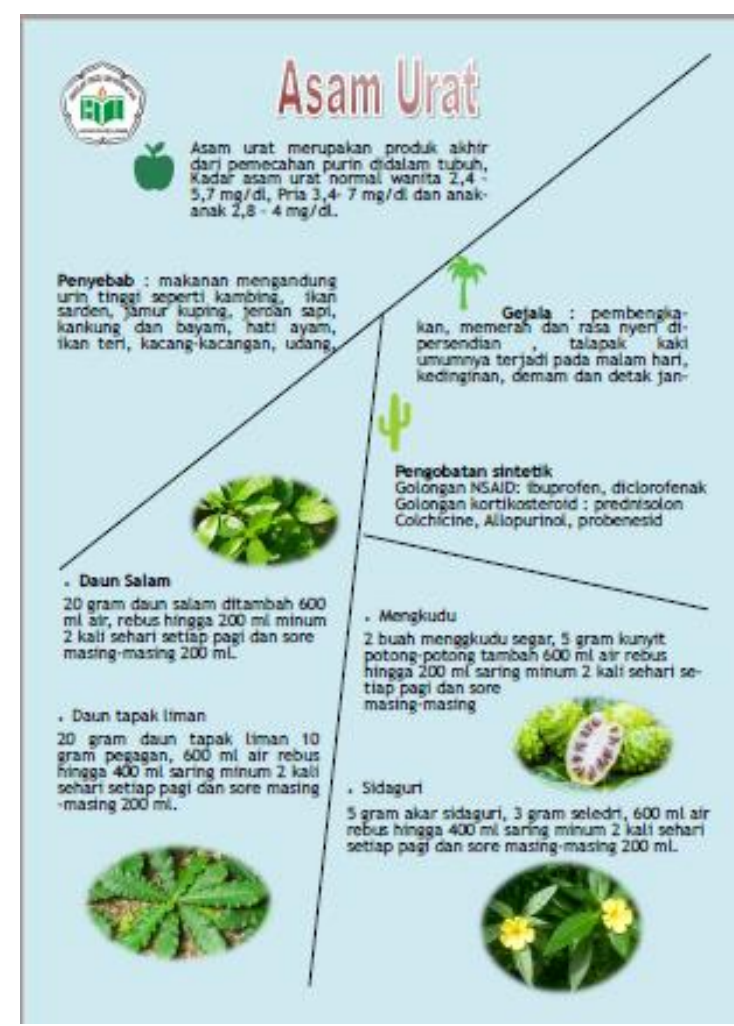

Gambar 2. Poster Penyakit Asam Urat(Boleu, Mangimbulude, \& Karwur, 2018).

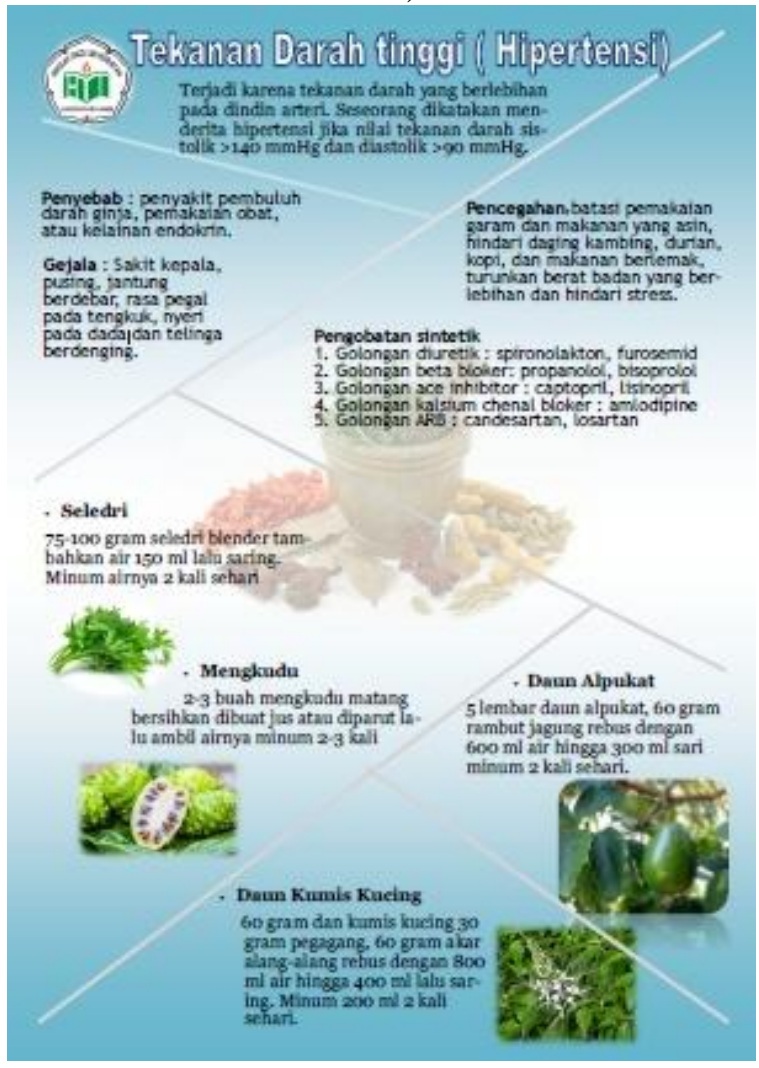

Gambar 3. Poster Penyakit Hipertensi(Sofiana \& et, 2018). 
Menurut Undang-Undang Kesehatan No. 23 Tahun 1992, obat adalah bahan atau panduan bahan-bahan yang siap digunakan untuk mempengaruhi atau menyelidiki system fisiologi atau keadaan patologi dalam rangka penetapan diagnosis, pencegahan, penyembuhan, pemulihan, peningkatan kesehatan dan kontrasepsi.

Sesuai Permenkes No. 917/ MENKES/ PER/ X/ 1993 tentang Wajib Daftar Obat Jadi, yang dimaksud dengan golongan obat adalah penggolongan yang dimaksudkan untuk peningkatan keamanan dan ketetapan penggunaan serta pengamanan distribusi yang terdiri dari obat bebas, obat bebas terbatas, obat wajib apotek, obat keras, psikotropika dan narkotika (Depkes, 1993).

Penggolongan obat berdasarkan mekanisme kerja yaitu obat yang bekerja untuk merangsang (stimulasi) dan menekan (depresi) fungsi spesifik dari sel tubuh, membunuh atau menghambat aktivitas selsel asing dan bakteri, menimbulkan aksi spesifik maupun non spesifik, dan mensubstitusi zat-zat tertentu yang diperlukan oleh tubuh. Adapun bentuk leaflet dapat di lihat pada gambar 7 dan 8 .

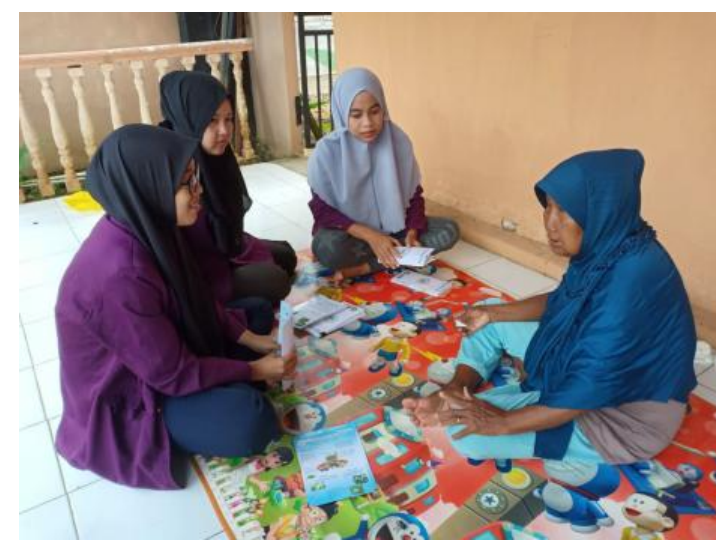

Gambar 4. Foto Kegiatan Penyuluhan

Sebelum dilakukannya penyuluhan masyarakat yang tidak paham mengenai penyakit Gastritis, Asam urat serta Hipertensi dan penggolongan obat sebanyak $18 \%$, sedangkan untuk kategori cukup paham sebanyak $41 \%$, kategori paham 26\% dan sangat paham $15 \%$.

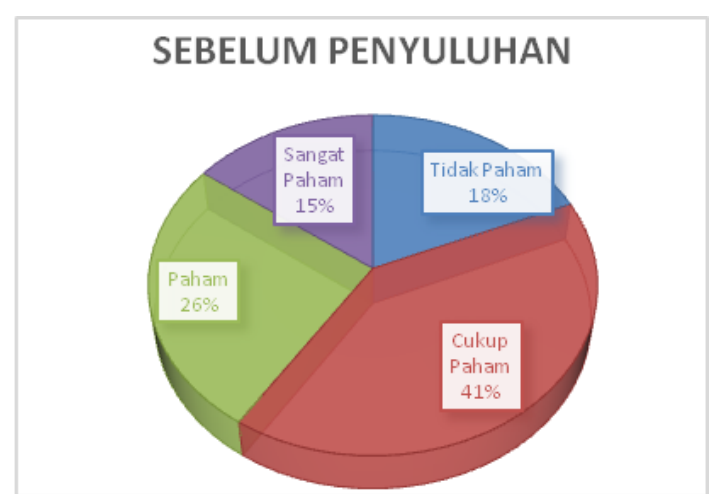

Diagram 1. sebelum penyuluhan

Setelah dilakukannya penyuluhan didapatkan hasil bahwa masyarakat mengalami peningkatan pengetahuan terkait penyakit Gastritis, Asam urat serta Hipertensi dan penggolongan obat sebanyak $19 \%$ pada kategori sangan paham dan kategori paham sebanyak 33\%. Lalu mengalami penurunan yang tidak terlalu signifikan sebelum penyuluhan pada kategori tidak paham $11 \%$ dan kategori cukup paham $37 \%$.

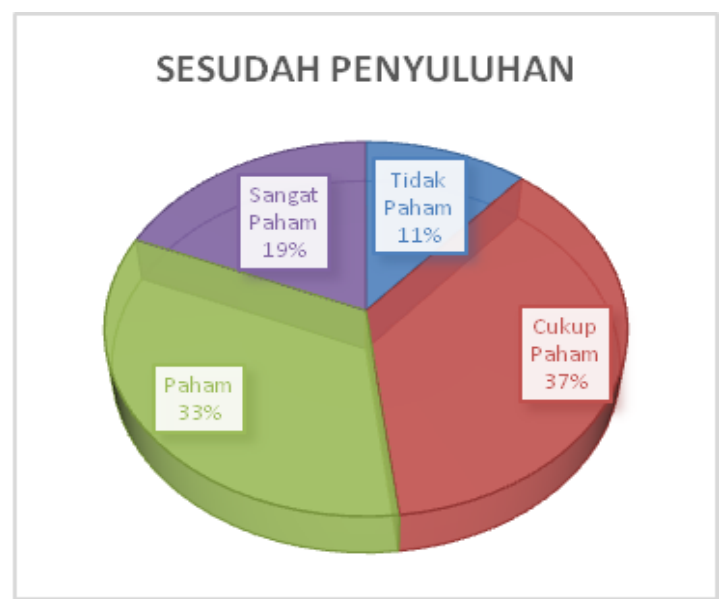

Diagram 2. sesudah penyuluhan

Hal ini menunjukan bahwa penyuluhan secara langsung dan tidak langsung cukup efektif untuk meningkatkan pengetahuan masyarakat setempat. Selisih pemahaman masyarakat dari sebelum dan sesudah dilakukannya penyuluhan sebesar $22 \%$. Hal ini menunjukkan adanya peningkatan pemahaman masyarakat dari penyuluhan informasi kesehatan yang di berikan.

KESIMPULAN DAN SARAN

1. Kesimpulan 
Dari hasil kegiatan ini maka dapat di simpulkan bahwa adanya pengaruh penyuluhan kesehatan sebelum dan sesudah terhadap tingkat pengetahuan masyarakat tentang penyakit Gastritis, Asam urat, Hipertensi dan penggolongan obat dengan peningkatan pemahaman.

\section{Saran}

Setelah dilakukannya penyuluhan kesehatan kepada masyarakat RT.09 Dusun Talang Parit Desa Kemingking Dalam diharapkan dapat diteruskan dan dimanfaatkan untuk kepentingan masyarakat setempat.

\section{UCAPAN TERIMA KASIH}

Ucapan terimakasih ini diberikan kepada Kepala Desa Kemingking Dalam, Kepala Dusun Talang Parit, Ketua RT.09 dan masyarakat yang telah memberi kesempatan kepada kami dan membantu kami dalam pelakasaan kegiatan pegabdian masyarakat di RT.09 Dusun Talang Parit Desa Kemingking Dalam Kabupaten Muaro Jambi Kecamatan Taman Rajo Provinsi Jambi.

\section{DAFTAR PUSTAKA}

Boleu, F., Mangimbulude, J. C., \& Karwur, F. F. (2018). Hyperurisemia Dan Hubungan Antara Asam Urat Darah Dengan Gula Darah Sewaktu Dan IMT Pada Komunitas Etnik Asli Di Halmahera Utara. Jurnal Ilmu Kesehatan Masyarakat, 9(2). https://doi.org/10.26553/jikm.2018.9. 2.96-106

Departemen Kesehatan, 1993, Peraturan Menteri Kesehatan Nomor 917/Menkes/Per/X/1993 tentang Wajib Daftar Obat Jadi. Pasa11 Ayat $1-3$
Haryani, S., \& Sahar, J. (2016). Penyuluhan Kesehatan Melalui Media Cetak Berpengaruh Terhadap Perawatan Hipertensi Pada Usia Dewasa Di Kota Depok. Jurnal Keperawatan Indonesia, 19(3), 161-168.

Maulana Heri D.J. (2013). Promosi Kesehatan. Jakarta: EGC

Mubin, A. Halim \& Risna Halim Mubin. (2016). Panduan Praktis Ilmu Penyakit Dalam: Diagnosis dan Terapi Edisi 3. Jakarta: EGC.

Muthia, F., Fitriangga, A., \& Yanti, S. N. (2016). Perbedaan Efektifitas Penyuluhan Kesehatan menggunakan Metode Ceramah dan Media Audiovisual (Film) terhadap Pengetahuan Santri Madrasah Aliyah Pesantren Khulafaur Rasyidin tentang TB Paru Tahun 2015. Jurnal Cerebellum, 2(4), 646-656.

Nuryati,S.Far.,MPH. (2017). Farmakologi. KEMENKES RI: Jakarta

Sofiana, L., \& et, all. (2018). Upaya Peningkatan Pengetahuan Tentang Hipertensi Melalui Metode Penyuluhan. Jurnal Pemberdayaan: Publikasi Hasil Pengabdian Kepada Masyarakat, 2(1), 171-176.

Tussakinah, W., Masrul, \& Burhan, I. R. (2018). Artikel Penelitian Hubungan Pola Makan dan Tingkat Stres terhadap Kekambuhan Gastritis di Wilayah Kerja Puskesmas Tarok Kota Payakumbuh Tahun 2017. Jurnal Kesehatan Andalas, 7(2), 217-225.

Undang-Undang Nomor 23 tahun 1992, Tentang Kesehatan, Penerbit Ariloka, Surabaya : 2000 